\title{
PENGARUH LIMBAH DETERGEN TERHADAP KESEHATAN IKAN
}

\author{
Resti Faumi ${ }^{1}$, Muhammad Radhi ${ }^{1}$ \\ ${ }^{1}$ Mahasiswa Program Studi Aquakultur. Fakultas Pertanian, Universitas Almuslim, Jalan Almuslim, \\ Matang Geulumpang Dua, Peusangan, Kabupaten Bireuen, Aceh 24261 \\ Email: ristianafaumi@gmail.com
}

\begin{abstract}
ABSTRAK
Deterjen adalah pembersih sintetis yang terbuat dari bahan-bahan turunan minyak bumi, yang terdiri dari bahan kimia yang dapat memberikan dampak negatif pada biota yang hidup di laut ataupun sungai. Deterjen tersebut bisa membuat ikan-ikan yang ada pada perairan menjadi terganggu khususnya pada organ-organ ikan seperti hati menyebabkan zat toksik yang masuk kedalam metabolisme memicu hati untuk bekerja lebih keras sehingga menimbulkan peradangan dan pembengkakan, insang menyebabkan zat toksik dapat merusak fungsi respirasi dari insang sehingga proses metabolisme dalam tubuh terganggu, sistem reproduksi menyebabkan indeks fisiologi berupa GSI pada ikan mengalami penurunan seiring dengan tingginya konsentrasi limbah detergen, bahkan bisa menggangu kelangsungan hidup ikan karena ikan tidak mampu untuk beradaptasi dengan kondisi yang semakin menipisnya ketersediaan oksigen terlarut dalam air.
\end{abstract}

Kata Kunci: Toksisitas, Limbah Detergen, Organ-organ ikan.

\section{PENDAHULUAN}

Toksisitas merupakan uji yang dilakukan untuk memperkirakan risiko yang berkaitan dengan pemaparan zat kimia dalam kondisi khusus karena kita ketahui bahwa tidak ada satupun zat kimia yang dapat dikatakan aman (bebas resiko) sepenuhnya, karena setiap zat kimia akan bersifat toksik pada tingkat dosis tertentu (Lu, 2006). Meningkat nya kadar zat-zat pencemar yang berbahaya dapat menimbulkan toksik atau racun sehingga mengganggu proses kehidupan dan setelah mencapai kadar tertentu dapat mematikan hewan peliharaan (Zulfahmi et al., 2017); (Zulfahmi et al., 2018); (Akmal et al., 2018d); (Muliari et al., 2019a); (Muliari et al., 2019b). Salah satu bahan pencemar yang dapat menimbulkan efek negatif bagi biota perairan adalah logam berat. Faktor lingkungan seperti toksik perairan dari dan kelainan genetik dapat mempengaruhi keabnormalan tulang rangka ikan (Zulfahmi et al., 2018); (Akmal et al., 2018a); (Akmal et al., 2018b); (Akmal et al., 2018c); (Akmal et al., 2019); (Zulfahmi et al., 2019). Detergen merupakan salah satu produk komersial yang digunakan untuk menghilangkan kotoran pada pencucian pakaian.

Umumnya detergen tersusun atas tiga komponen yaitu, surfaktan (sebagai bahan dasar detergen) sebesar 20-30\%, builders (senyawa fosfat) sebesar $70-80 \%$, dan bahan aditif (pemutih dan pewangi) yang relative sedikit yaitu $2-8 \%$. Surface Active Agent (surfaktan) pada detergen digunakan untuk proses pembasahan dan pengikat kotoran, sehingga sifat dari detergen dapat berbeda tergantung jenis surfaktannya (Kirk dan Othmer, 1982). Limbah detergen terhadap organisme air dapat menyebabkan kerusakan jaringan organisme pada organ ikan seperti insang dan hati (Darmono, 2001).

Insang ikan adalah respirasi utama yang bekerja dengan mekanisme difusi permukaan dari gas-gas respirasi (oksigen dan karbondioksida) antara darah dan air, dengan demikian peubahanperubahan lingkungan perairan akan secara langsung berdampak kepada struktur (Saputra 2013). Limbah detergen juga berpotensi terhadap organ ikan lainnya pada hati. Hati merupakan organ yang banyak berhubungan dengan senyawa kimia sehingga mudah terkena efek toksik (Loomis 1978). Hal ini dikarenakan zat toksik detergen yang mempengaruhi sistem metabolisme gonad ikan Menurut Larsson (2005). Kematangan gonad adalah tahapan tertentu perkembangan gonad sebelum sesudah memijah, selama proses reproduksi sebagian energi dipakai untuk perkembangan gonad. Selain itu deterjen dalam badan air dapat merusak Kelangsungan hidup ikan. Kelangsungan hidup adalah jumlah individu dalam pupolasi yang mati selama periode waktu tertentu. Dalam studi populasi biologiwan lebih tertarik pada mengapa organisme mati pada usia tertentu.

\section{PEMBAHASAN}

\section{Kerusakan pada insang}

Insang ikan adalah respirasi utama yang bekerja dengan mekanisme difusi permukaan dari gas-gas respirasi (oksigen dan karbondioksida) antara darah dan air, dengan demikian peubahanperubahan lingkungan perairan akan secara langsung berdampak kepada struktur (Saputra 2013). Menurut Kusriani (2012) bahwa pengaruh 
zat toksik terhadap ikan menyebabkan morfologi insang berubah dan menyebabkan kematian dalam periode panjang. Selain itu, zat toksik dapat merusak fungsi respirasi dari insang sehingga proses metabolisme dalam tubuh terganggu. Deterjen yang bereaksi dengan air akan menimbulkan busa pada bagian permukaan air sehingga secara langsung menghambat proses difusi udara bebas ke dalam media air dalam akuarium. Hal ini berdampak pada menipisnya persediaan oksigen terlarut dalam air sehingga ikan mas kesulitan bernapas dan berdampak terhadap peningkatan frekuensi bukaan operkulum dengan keruskan inti sel dan mengecilnya jaringan sel hati.

\section{Kerusakan pada hati}

Hati merupakan organ yang banyak berhubungan dengan senyawa kimia sehingga mudah terkena efek toksik (Loomis 1978). Limbah detergen menyebabkan zat toksik yang masuk kedalam metabolisme memicu hati untuk bekerja lebih keras sehingga menimbulkan peradangan dan pembengkakan. Menurut Larsson (2005) Liver Somatic Index (LSI) mencerminakan status metabolisme. Ukuran hati yang semakin besar menunjukkan aktifitas metabolisme yang tinggi. Organ selanjutnya yang berpontensi terkena limbah detergen yaitu gonad (IGS).

\section{Kerusakan pada reproduksi}

Kematangan gonad adalah tahapan tertentu perkembangan gonad sebelum sesudah memijah, selama proses reproduksi sebagian energi dipakai untuk perkembangan gonad. Pada uji penelitian menyatakan bahwa indeks fisiologi berupa GSI pada ikan mengalami penurunan seiring dengan tingginya konsentrasi limbah detergen. Hal ini dikarenakan zat toksik detergen yang mempengaruhi sistem metabolisme gonad ikan. Menurut Larsson (2005) Gonade Somatic Index (GSI) GSI yang turun (kecil) menunjukkan kesuburan yang rendah, mungkin disebabkan oleh berkurangnya alokasi energi untuk bereproduksi.

\section{Kelangsungan hidup ikan}

Pemaparan deterjen pada hari ke-14 terlihat kematian pada uji perlakuan tersebut mencapai $(91,67 \%)$. Hal ini menunjukkan bahwa semakin tinggi konsentrasi deterjen bubuk yang dipaparkan akan menurunkan kelangsungan hidup ikan karena ikan tidak mampu untuk beradaptasi dengan kondisi semakin menipisnya ketersediaan oksigen terlarut dalam air. Hal ini menyebabkan terganggunya proses respirasi dan berlanjut pada kematian ikan, yang dibuktikan dengan kematian ikan-ikan dengan posisi tutup insang (operkulum) yang terbuka bahkan sampai mengeluarkan darah pada bagian insang (Suparjo, 2010).

\section{KESIMPULAN}

Deterjen adalah pembersih sintetis yang terbuat dari bahan-bahan turunan minyak bumi, Deterjen tersebut bisa membuat biota yang ada pada perairan menjadi terganggu khususnya pada organ-organ ikan seperti hati menyebabkan zat toksik yang masuk kedalam metabolisme memicu hati untuk bekerja lebih keras sehingga menimbulkan peradangan dan pembengkakan, insang menyebabkan zat toksik dapat merusak fungsi respirasi dari insang sehingga proses metabolisme dalam tubuh terganggu, sistem reproduksi menyebabkan indeks fisiologi berupa GSI pada ikan mengalami penurunan seiring dengan tingginya konsentrasi limbah detergen, bahkan bisa menggangu kelangsungan hidup ikan karena ikan tidak mampu untuk beradaptasi dengan kondisi yang semakin menipisnya ketersediaan oksigen terlarut dalam air.

\section{DAFTAR PUSTAKA}

Akmal, Y., Saifuddin, F., \& Zulfahmi, I. (2018). Anatomi Skeleton Ikan Keureling. In Prosiding Seminar Nasional (Vol. 1, No. 1).

Akmal, Y., \& Rahardjo, M. F. (2018). Morphology of appendicular skeleton of the Thai mahseer's Tor tambroides (Bleeker, 1854). Jurnal Iktiologi Indonesia, 18(3), 261-274. https://doi.org/10.32491/jii.v18i3.443

Akmal, Y., Zulfahmi, I., \& Saifuddin, F. (2018). Karak-teristik morfometrik dan skeleton ikan keureling (Tor tambroides Bleeker 1854). Jurnal Ilmiah Samudra Akuatika, 2(1), 35-44.

Akmal, Y., Zulfahmi, I., Juanda, R., Karja, N. W. K., \& Nisa, C. (2018, December). Histopathological changes in gill of Nile tilapia (Oreochromis niloticus) after palm oil mill effluent exposure. In IOP Conference Series: Earth and Environmental Science (Vol. 216, No. 1, p. 012003). IOP Publishing.

Akmal, Y., Saifuddin, F., \& Zulfahmi, I. (2019). Karakteristik Morfometrik Dan Studi Osteologi Ikan Keureling. Prosiding Biotik, 5(1).

Darmono. (2001). Lingkungan Hidup dan Pencemaran. UI-Press.

Krik, R.E. and Othmer, D.F,. (1982) "Encyclopedia of Chemical Technology", vol, 1, 2nd edition, A Willey Interscience Publicatio, John Wiley and Sons Co.

Kusriani, P,. Wisjanarko dan Rohmawati,N. (2012). Uji Pengasuh Sublethal Pestisida Diazinon 60 EC terhadap Rasio Konveksi pakan (FCR) dan Pertumbuhan Ikan Mas (Crypinus carpio L). Jurnal Penelitian Perikanan 1 (1): 36-42.

Larson, T.A,. (2005). Gastrointestinal Infestious, 2045-2046, dalam Dipiro, J.T., Wells, B.G., Schwinghammer, T.L., Hamilition, C.W., 
Pharmacoterapy Handbook, Edisin 5, Graw Hill Companies, USA.

Loomis, TA. (1978). Tokailogi Dasar. Penerjemah Donatus. Semarang : IKIP.

Lu. (2006). Toksikologi Dasar. Universitas Indonesia Press. Jakarta.

Muliari, M., Zulfahmi, I., \& Akmal, Y. (2019). Ekotoksikologi Akuatik. Bogor: IPB Press.

Muliari, M., Zulfahmi, I., Akmal, Y., Karja, N. W. K., Nisa, C., \& Sumon, K. A. (2019b). Effects of palm oil mill effluent on reproductive hormone of female nile tilapia, oreochromis niloticus (linnaeus 1758). Adv. Anim. Vet. Sci, 7(11), 1035-1041.

Saputra, H. M., Marusin, N., dan Santoso, P. (2013). Struktur Histologi Insang dan Kadar Hemoglobin Ikan Asang (Osteochilus hasseltii C.V) di Danau Singkarak dan Maninjau, Sumatera Barat. J. Bio. UA. 2303-2162.

Suparjo. (2010). Analisis Bahan pakan secara Kimiawi: Analisis Proksimat dan Analisis Serat. Fakultas Peternakan Universitas Jambi. Jambi.

Zulfahmi, I., Muliari, M., \& Akmal, Y. (2017, November). Indeks Hepatosomatik Dan Histopatologi Hati Ikan Nila (Oreochromis Niloticus Linnaeus 1758) Yang Dipapar Limbah Cair Kelapa Sawit. In Prosiding SEMDI-UNAYA (Seminar Nasional Multi Disiplin Ilmu UNAYA) (Vol. 1, No. 1, pp. 301314).

Zulfahmi, I,. Muliari, Akmal, Y,. Batubara AS. (2018) Reproductive performance and gonad histopathology of famale Nile Tilapia (Orechromis niloticusLinnaeus 1758). Exposed to palm oil mill effluent. The EgyptianJournal of Aquatic Research 44: 327-332.

Zulfahmi, I., Akmal, Y., \& Batubara, A. S. (2018). The morphology of Thai mahseer's Tor tambroides (Bleeker, 1854) axial skeleton (ossa vertebrae). Jurnal Iktiologi Indonesia, 18(2), 139-149.

Zulfahmi, I., Akmal Y., Muliari. (2019). Osteologi Ikan Keureling (Tor tambroides). Bogor: IPB Press; ISBN: 978-602-440-641-7 